\title{
Screening of Sour Passion Fruit for Reaction to Bacterial Spot and Passion Fruit Woodiness Disease
}

\author{
Anne Pinheiro Costa $^{1}$, Isadora Nogueira ${ }^{1}$, José Ricardo Peixoto ${ }^{1} \&$ Luiz Eduardo Bassay Blum $^{2}$ \\ ${ }^{1}$ Faculty of Agronomy and Veterinary Medicine, University of Brasilia, Brasilia, Brazil \\ ${ }^{2}$ Institute of Biological Sciences, Department of Plant Pathology, University of Brasilia, Brasilia, Brazil \\ Correspondence: Anne Pinheiro Costa, Faculty of Agronomy and Veterinary Medicine, University of Brasilia, \\ Brasilia, DF, Brazil. Tel: 55-61-983-508-322. E-mail: annecosta@gmail.com
}

\author{
Received: May 12, $2019 \quad$ Accepted: July 17, $2019 \quad$ Online Published: January 15, 2020 \\ doi:10.5539/jas.v12n2p130 URL: https://doi.org/10.5539/jas.v12n2p130
}

\begin{abstract}
The development of resistant varieties is a promising strategy for bacterial spot disease (Xanthomonas axonopodis pv. passiflorae-Xap) and passion fruit woodiness disease (PWD; Cowpea aphid-borne mosaic virus-CABMV) control in sour passion fruit (Passiflora edulis Sims). This study aimed at evaluating the reaction of 12 sour passion fruit half-sib progenies to both mechanically inoculated Xap and CABMV, under protected cultivation. The bacterial spot and PWD severity degrees observed reveal the existence of variability within progenies. MAR20\#2005 and BRS GA1 revealed the lowest bacterial disease severity scores while MAR20\#41, MAR20\#2005, and Rosa Intenso 1 showed the lowest PWD severity scores. MAR20\#41 presented the lowest disease incidence in all evaluations, demonstrating a slow increase in the number of plants with symptoms over time. Also, MAR20\#41 stood out as the progeny with the greatest number of plants presenting resistance to PWD at the end of the study. Among the progenies selected, MAR20\#2005 was the most promising for presenting the lowest severity scores for both bacterial spot and PWD.
\end{abstract}

Keywords: Cowpea aphid-borne mosaic virus, disease resistance, genetic breeding, Passiflora edulis Sims, Xanthomonas axonopodis pv. passiflorae

\section{Introduction}

Bacterial spot disease, caused by Xanthomonas axonopodis pv. passiflorae (Xap), is one of the major disease limiting yield in sour passion fruit (Passiflora edulis Sims) orchards. The pathogen infects leaves and fruits, causing expressive damage especially in the hot and humid seasons (Junqueira, Sussel, Junqueira, Zacaroni, \& Braga, 2016). Infection occurs through natural openings and mechanical injuries. In the leaves, the disease starts with small, translucent, and soaked lesions which subsequently become necrotic, with a reddish-brown color (Peruch, Colariccio, \& Schroeder, 2011). In addition, a chlorotic halo may also surround lesions (Junqueira et al., 2016). As disease severity increase, leaf drop increase, and yield is reduced. Xap may reach the vascular bundles, resulting in a systemic invasion of the whole plant, which causes plant drought and death in susceptible cultivars (Peruch et al., 2011; Junqueira et al., 2016).

Also, passion fruit woodiness disease (PWD), caused by Cowpea aphid-borne mosaic virus (CABMV), is the most important viral-induced disease of sour passion worldwide (Nascimento et al., 2006). Plants affected with PWD have both yield and lifespan reduced. In some regions, the passion fruit cultivation may be unfeasible due to the destructive potential of the disease (Carvalho, Lorencetti, \& Benin, 2015). Diseased plants produce small, woody, and deformed fruits, which became unmarketable. Leaves display severe mosaic, hardening, distortion, and puckering due to the different growth rates of the infected tissue (Nascimento et al., 2006).

The development of resistant passion fruit varieties is a promising strategy for bacterial spot and PWD control. Several sour passion fruit genotypes have demonstrated resistance to bacterial spot disease (Viana, Pires, Peixoto, Junqueira, \& Blum, 2014a), but nowadays, there are no reports on resistant Passiflora edulis genotypes to PWD (Santos et al., 2015). Naturally occurring multiple resistance to numerous pathogens have been recorded for a few crops (Melo et al., 2008; Neder, Pinto, Melo, Lepre, \& Peixouto, 2010; Wisser et al., 2011). However, multiple pathogen reaction studies are limited for sour passion fruit (Costa et al., 2018a, 2018b). Most studies performed for this crop under protected cultivation are focused on mechanical inoculation of a single pathogen 
(Fuhrmann et al., 2014; Viana et al., 2014a, 2014b). Nevertheless, reaction to a single disease does not reflect what is observed under field conditions, since multiple diseases affect simultaneously the plants under that circumstance. In this context, the objective of this study was to evaluate the reaction of 12 sour passion fruit half-sib progenies to mechanically inoculated Xap and CABMV, under protected conditions.

\section{Method}

\subsection{Site Characteristics}

The experiment was performed under protected cultivation, between January and May 2015, at the Experiment Station of the University of Brasilia (UnB; $16^{\circ} \mathrm{S}$ and $48^{\circ} \mathrm{W}, 1010 \mathrm{~m}$ above sea level), located in Brasilia, DF, Brazil. The climate of the region is tropical seasonal (Aw) according to the Köppen classification (Alvares, Stape, Sentelhas, Gonçalves, \& Sparovek, 2013), presenting two well defined seasons: the hot and rainy (October to April) and the cold and dry (May to September). The minimum and maximum temperatures registered during the studied period were 14 and $30{ }^{\circ} \mathrm{C}$, respectively. Minimum relative humidity of $61 \%$ and maximum relative humidity of $82 \%$ were recorded.

\subsection{Plant Material and Disease Evaluations}

The genotypes were developed by UnB and the Brazilian Agricultural Research Corporation (Embrapa) and were selected based on disease resistance, fruit quality and yield. The half-sib progenies were obtained and the processes of seedling management isolate collection, pathogen inoculation, and disease evaluation were performed as described by Costa et al. (2018a).

The experiment consisted of inoculating with Xap sour passion fruit plants on 30 January 2015, in the wet season, followed by inoculation with CABMV on 18 May 2015, in the dry season, on the same plants. Bacteria inoculation was performed using the UnB-1392 Xap strain. The inoculation was performed with the aid of four needles which were simultaneously immersed in the bacterial suspension $\left(\sim 1 \times 10^{6} \mathrm{CFU} \mathrm{mL}^{-1}\right)$ and then used to perforate the adaxial leaf surface of three leaves per plant. After inoculation, plants were kept in a humid chamber for $72 \mathrm{~h}$. Disease incidence (\% plants infected) and disease severity (\% total leaf area with necrotic lesions) were assessed at 7-day intervals after disease symptoms were first detected. The first of five evaluations was performed 12 days after inoculation. A 0 to 5 scale was used for bacterial spot severity assessment, as follows: 0 - no symptoms; $1-1$ to $10 \%$ of total leaf area with necrotic lesion; $2-11$ to $25 \%$ of total leaf area with necrotic lesion; $3-26$ to $50 \%$ of total leaf area with necrotic lesion; 4 -more than $50 \%$ of total leaf area with necrotic lesion; and 5-leaf drop (Costa et al., 2018a). Based on the mean disease severity (DS) scores obtained from this scale plants were classified, according to the resistance reaction, as: resistant (R), $0 \leq \mathrm{DS}<1$; moderately resistant (MR), $1 \leq \mathrm{DS}<2$; moderately susceptible (MS), $2 \leq \mathrm{DS}<3$; susceptible (S), $3 \leq \mathrm{DS}<4$; and highly susceptible (HS), DS $\geq 4$ (Viana et al., 2014a). Plants were pruned at the end of the bacterial spot disease assessments and fertilized every two weeks with urea $\left(0.1 \mathrm{~g} \mathrm{plant}^{-1}\right.$ at each fertilization event), until CABMV inoculation.

The CABMV isolate was collected from sour passion fruit plants at Núcleo Rural Pipiripau, Planaltina, DF. Inoculation was mechanically performed in three young leaves per plant by light friction of the adaxial leaf surface with a vegetable extract obtained from the maceration of the leaves showing severe symptoms of CABMV infection, such as mosaic, leaf deformations, and leaf blade wrinkling. Disease incidence (\% of plants infected) and disease severity (leaf symptoms) were recorded at a 7-day interval after disease symptoms were first detected. The first of five evaluations was performed 21 days after inoculation. A 1 to 4 scale was used for PWD severity assessment, as follows: 1-no symptoms; 2-mild mosaic and no leaf deformation; 3-mild mosaic, leaf blade wrinkling, and deformation; 4 - severe mosaic, leaf blade wrinkling, and deformation (Viana et al., 2014b). Based on the DS obtained from this scale, plants were classified, according to the resistance reaction, as: $\mathrm{R}, 1 \leq \mathrm{DS} \leq 1.5$; MS, $1.5<\mathrm{DS} \leq 2.5$; $\mathrm{S}, 2.5<\mathrm{DS} \leq 3.5$; HS, $3.5<\mathrm{DS} \leq 4$ (Costa et al., 2018a).

\subsection{Experimental Design and Data Analysis}

The experiment was carried out as a randomized block design with subdivided parcels comprised of 12 treatments (progenies), four repetitions, six replications per progeny, and five evaluations. Interactions between progenies and evaluation date were evaluated by analysis of variance. Disease severity and incidence heritability, genetic and environmental coefficient of variation ratio (GCV/ECV), and phenotypic correlations between disease severity and incidence were calculated. Correlation intensity was classified as suggested by Carvalho et al. (2004): $\mathrm{r}=0$ (null); $0<|\mathrm{r}| \leq 0.30$ (weak); $0.30<|\mathrm{r}| \leq 0.60$ (medium); $0.60<|\mathrm{r}| \leq 0.90$ (strong); $0.90<|\mathrm{r}| \leq 1$ (very strong); and $|\mathrm{r}|=1$ (perfect). The area under the disease progress curve (AUDPC) was calculated as an attempt to differentiate progenies regarding their resistance to bacterial spot and PWD using DS score data 
collected in the five evaluation dates (Campbell \& Madden, 1990). All means were grouped by the Scott-Knott's test $(\mathrm{P} \leq 0.05)$ and analyses were performed using Genes software (v. 1990.2017.37).

\section{Results and Discussion}

Bacterial spot severity and incidence assessments did not identify any difference among progenies $(\mathrm{P}>0.05)$. All progenies reached scores above 3.0 and were classified as susceptible, according to the mean number obtained from the grading scale (Table 1). Despite the lack of difference among progenies, it is important to emphasize that MAR20\#2005 (3.5) and BRS GA1 (3.6) revealed severity scores 10.3 and 7.7\%, respectively, lower than FB200 (3.9). Genotype susceptibility was also observed in other studies when a distinct Xap strain (UnB-1393) was inoculated on sour passion fruit plants using the same bacterial suspension concentration in the wet (Costa et al., 2018a) and dry (Nogueira, 2016; Costa et al., 2018b) seasons. However, lower severity scores and progeny $\times$ evaluation date interaction were recorded during the dry season both by Nogueira (2016) and Costa et al. (2018b) for progenies of the same genotypes evaluated in this study. This information reflects the influence of environmental conditions on the response of genotypes to pathogen inoculation. Consequently, it indicates the need for performing disease severity evaluations all year long as a strategy for accurate selection of resistant materials.

Differences were verified among evaluations one to four $(\mathrm{P} \leq 0.01)$, indicating an increase in bacterial spot severity with time. At the fifth evaluation, disease severity had already achieved its maximum and did not differ from the fourth evaluation for any progeny (Table 1).

Table 1. Bacterial spot disease severity (DSE and DS) and resistance reaction (RR) in sour passion fruit (Passiflora edulis Sims) mechanically inoculated with Xanthomonas axonopodis pv. passiflorae, in Brasilia, DF, Brazil

\begin{tabular}{llllllll}
\hline \multirow{2}{*}{ Progeny } & \multicolumn{4}{c}{ Severity at each evaluation date (DSE) } & \multicolumn{2}{c}{ RS } & \\
\cline { 2 - 6 } & E1 & E2 & E3 & E4 & E5 & & \\
\hline FB200 & 1.0 & 3.9 & 4.7 & 5.0 & 5.0 & $3.9 \mathrm{a}$ & $\mathrm{S}$ \\
Rosa Intenso 1 & 1.0 & 3.3 & 4.2 & 4.7 & 5.0 & $3.7 \mathrm{a}$ & $\mathrm{S}$ \\
MAR20\#39 & 1.0 & 3.7 & 4.5 & 4.9 & 5.0 & $3.8 \mathrm{a}$ & $\mathrm{S}$ \\
UnB2015-2 & 1.3 & 3.5 & 4.4 & 4.8 & 4.9 & $3.8 \mathrm{a}$ & $\mathrm{S}$ \\
Rosa Intenso 2 & 1.1 & 3.2 & 4.6 & 4.8 & 5.0 & $3.7 \mathrm{a}$ & $\mathrm{S}$ \\
MAR20\#41 & 1.1 & 3.3 & 4.4 & 4.8 & 4.9 & $3.7 \mathrm{a}$ & $\mathrm{S}$ \\
MAR20\#2005 & 1.0 & 2.9 & 4.2 & 4.8 & 4.9 & $3.5 \mathrm{a}$ & $\mathrm{S}$ \\
Rubi Gigante 2 & 1.1 & 3.5 & 4.4 & 4.7 & 4.8 & $3.7 \mathrm{a}$ & $\mathrm{S}$ \\
MAR20\#24 & 1.1 & 3.5 & 4.5 & 4.7 & 4.8 & $3.7 \mathrm{a}$ & $\mathrm{S}$ \\
AR2 & 1.1 & 3.3 & 4.4 & 4.8 & 4.9 & $3.7 \mathrm{a}$ & $\mathrm{S}$ \\
EC-3-0 & 1.1 & 3.0 & 4.4 & 5.0 & 5.0 & $3.7 \mathrm{a}$ & $\mathrm{S}$ \\
BRS GA1 & 1.0 & 3.2 & 4.3 & 4.7 & 4.9 & $3.6 \mathrm{a}$ & $\mathrm{S}$ \\
Mean & $1.1 \mathrm{D}$ & $3.4 \mathrm{C}$ & $4.4 \mathrm{~B}$ & $4.8 \mathrm{~A}$ & $4.9 \mathrm{~A}$ & &
\end{tabular}

Note. $\mathrm{E}=$ Evaluations; $\mathrm{DS}=$ Mean severity scores of five evaluations. Different letters indicate a significant difference (Scott-Knott's test, $\mathrm{P} \leq 0.05$ ).

Progenies presented high disease incidence early at evaluation one (97.8\%). Consequently, differences could only be detected between the first two evaluations $(\mathrm{P} \leq 0.01)$. Progenies showed 100.0\% disease incidence at evaluation two, except for MAR20\#24 (98.4\%), which achieved 100.0\% incidence later during evaluation four (Table 2). 
Table 2. Bacterial spot disease incidence (DIE and DI; \%) in sour passion fruit (Passiflora edulis Sims) mechanically inoculated with Xanthomonas axonopodis pv. passiflorae, in Brasilia, DF, Brazil

\begin{tabular}{lllllll}
\hline \multirow{2}{*}{ Progeny } & \multicolumn{5}{c}{ Incidence at each evaluation date (DIE) } & \multirow{2}{*}{ DI } \\
\cline { 2 - 5 } & E1 & E2 & E3 & E4 & E5 & \\
\hline FB200 & 100.0 & 100.0 & 100.0 & 100.0 & 100.0 & $100.0 \mathrm{a}$ \\
Rosa Intenso 1 & 97.1 & 100.0 & 100.0 & 100.0 & 100.0 & $99.4 \mathrm{a}$ \\
MAR20\#39 & 98.3 & 100.0 & 100.0 & 100.0 & 100.0 & $99.7 \mathrm{a}$ \\
UnB2015-2 & 100.0 & 100.0 & 100.0 & 100.0 & 100.0 & $100.0 \mathrm{a}$ \\
Rosa Intenso 2 & 98.3 & 100.0 & 100.0 & 100.0 & 100.0 & $99.7 \mathrm{a}$ \\
MAR20\#41 & 100.0 & 100.0 & 100.0 & 100.0 & 100.0 & $100.0 \mathrm{a}$ \\
MAR20\#2005 & 95.4 & 100.0 & 100.0 & 100.0 & 100.0 & $99.1 \mathrm{a}$ \\
Rubi Gigante 2 & 100.0 & 100.0 & 100.0 & 100.0 & 100.0 & $100.0 \mathrm{a}$ \\
MAR20\#24 & 94.1 & 98.4 & 98.4 & 100.0 & 100.0 & $98.2 \mathrm{a}$ \\
AR2 & 95.8 & 100.0 & 100.0 & 100.0 & 100.0 & $99.2 \mathrm{a}$ \\
EC-3-0 & 97.2 & 100.0 & 100.0 & 100.0 & 100.0 & $99.4 \mathrm{a}$ \\
BRS GA1 & 97.1 & 100.0 & 100.0 & 100.0 & 100.0 & $99.4 \mathrm{a}$ \\
Mean & $97.8 \mathrm{~B}$ & $99.9 \mathrm{~A}$ & $99.9 \mathrm{~A}$ & $100.0 \mathrm{~A}$ & $100.0 \mathrm{~A}$ & \\
\hline
\end{tabular}

Note. $\mathrm{E}=$ Evaluations; DI $=$ Mean incidence scores of five evaluations. Different letters indicate a significant difference (Scott-Knott's test, $\mathrm{P} \leq 0.05$ ).

PWD severity assessments did not identify any difference among progenies $(\mathrm{P}>0.05)$ and they were classified as moderately susceptible, in accordance with the mean number obtained from the grading scale (Table 3 ). These findings are corroborated by Nogueira (2016), who also recorded moderate susceptibility of progenies Rosa Intenso, MAR20\#41, EC-3-0, and BRS GA1 when inoculated with a distinct CABMV isolate (UnB-Fal) in the same season of this study. Although no differences were detected, progeny MAR20\#41 (1.6) exhibited 30.4\% less severity while progenies MAR20\#2005 (1.9) and Rosa Intenso 1 (1.9) presented 17.4\% less severity than AR2 (2.3) and MAR20\#39 (2.3). These results demonstrate that such plant materials present a slightly greater resistance to PWD. After five evaluations, plants presenting resistance to PWD could be observed in all progenies. MAR20\#41 stood out as the progeny with the greatest number of resistant plants at the end of the study $(60.0 \%)$ This data is supported by Costa et al. (2018b), who recently recorded 63.0\% of resistant plants at the end of five weeks of evaluation when MAR20\#41 was inoculated with the isolate UnB-Fal in a distinct season.

Table 3. Passion fruit woodiness disease (PWD) severity (DSE and DS), resistance reaction (RR), and percentage of resistant plants (\%RP) in sour passion fruit (Passiflora edulis Sims) mechanically inoculated with Cowpea aphid-borne mosaic virus (CABMV), in Brasilia, DF, Brazil

\begin{tabular}{|c|c|c|c|c|c|c|c|c|}
\hline \multirow{2}{*}{ Progeny } & \multicolumn{5}{|c|}{ Severity at each evaluation date (DSE) } & \multirow{2}{*}{ DS } & \multirow{2}{*}{$\mathrm{RR}$} & \multirow{2}{*}{$\% \mathrm{RP}$} \\
\hline & E1 & E2 & E3 & E4 & E5 & & & \\
\hline FB200 & 1.7 & 1.9 & 2.1 & 2.2 & 2.3 & $2.0 \mathrm{a}$ & MS & 15.0 \\
\hline Rosa Intenso 1 & 1.4 & 1.8 & 2.1 & 2.2 & 2.2 & $1.9 \mathrm{a}$ & MS & 26.3 \\
\hline MAR20\#39 & 1.7 & 2.3 & 2.3 & 2.5 & 2.5 & $2.3 \mathrm{a}$ & MS & 23.8 \\
\hline UnB2015-2 & 1.6 & 1.8 & 2.3 & 2.5 & 2.5 & $2.1 \mathrm{a}$ & MS & 20.0 \\
\hline Rosa Intenso 2 & 1.5 & 1.7 & 2.1 & 2.3 & 2.3 & $2.0 \mathrm{a}$ & MS & 20.0 \\
\hline MAR20\#41 & 1.2 & 1.5 & 1.8 & 1.9 & 2.0 & $1.6 \mathrm{a}$ & MS & 60.0 \\
\hline MAR20\#2005 & 1.3 & 1.7 & 2.1 & 2.2 & 2.1 & $1.9 \mathrm{a}$ & MS & 4.6 \\
\hline Rubi Gigante 2 & 1.4 & 2.0 & 2.3 & 2.4 & 2.4 & $2.1 \mathrm{a}$ & MS & 13.0 \\
\hline MAR20\#24 & 1.8 & 2.1 & 2.3 & 2.3 & 2.4 & $2.2 \mathrm{a}$ & MS & 10.5 \\
\hline AR2 & 1.9 & 2.2 & 2.4 & 2.5 & 2.5 & $2.3 \mathrm{a}$ & MS & 10.0 \\
\hline EC-3-0 & 1.3 & 1.6 & 2.2 & 2.3 & 2.3 & $2.0 \mathrm{a}$ & MS & 16.7 \\
\hline BRS GA1 & 1.5 & 1.9 & 2.4 & 2.5 & 2.6 & $2.2 \mathrm{a}$ & MS & 4.4 \\
\hline Mean & $1.5 \mathrm{D}$ & $1.9 \mathrm{C}$ & $2.2 \mathrm{~B}$ & $2.3 \mathrm{~A}$ & $2.4 \mathrm{~A}$ & & & \\
\hline
\end{tabular}

Note. $\mathrm{E}=$ Evaluations; $\mathrm{DS}=$ Mean severity scores of five evaluations; $\% \mathrm{RP}=$ Percentage of resistant plants at the end of the study, 49 days after inoculation. Different lowercase letters within columns and uppercase letters within rows indicate significant differences (Scott-Knott's test, $\mathrm{P} \leq 0.05$ ). 
Differentiating genotypes for disease resistance is often found to be difficult since variability to disease resistance in sour passion fruit is low (Junqueira, Anjos, Silva, Chaves, \& Gomes, 2003). Thus, several studies have indicated greater variability for disease resistance within progenies than among progenies (Junqueira et al., 2003; Fuhrmann et al., 2014; Costa et al., 2018b). In this context, statistical and genetics data become useful tools during genotype selection with focus on disease resistance. Therefore, any marginal difference among and within progenies is valuable in providing information for resistance selection and must not be disregarded (Fuhrmann et al., 2014).

Despite the influence of environmental conditions, recent studies (Nogueira, 2016; Costa et al., 2018a, 2018b) have demonstrated the superior performance of BRS GA1, MAR20\#41, MAR20\#2005, and Rosa Intenso progenies, which have shown lower bacterial spot and PWD severities in both wet and dry seasons or resistant plants at the end of a series of evaluations. These results have been used as tools to support and guide continuous selection and improvement of promising genotypes which are currently used as parents in intra and interspecific crossings. The use of resistant genotypes as parents in interspecific crosses can be considered strategic in the introgression of resistance genes into the desired genotypes. Furhmann et al. (2014), for example, recorded high resistance to different isolates of $X$. axonopodis pv. passiflorae in genotypes obtained from crossing the commercial P. edulis flavicarpa with the wild species P. setacea and P. caerulea. Similarly, Bellon (2014) reported lower disease severity scores in interspecific hybrids than in commercial cultivars when genotypes resulting from crossing $P$. edulis flavicarpa $\times$ P. setacea and $P$. edulis flavicarpa $\times$ P. caerulea were tested for resistance to PWD. The main objective of our passion fruit breeding program is to accomplish multiple disease resistance. Thus, the results here reported indicate the potential of such genotypes in order to achieve this goal regarding bacterial spot and PWD.

An interaction between progenies and evaluation dates was observed for PWD incidence $(\mathrm{P} \leq 0.01)$ (Table 4). MAR20\#41 presented the lowest disease incidence in all evaluations, demonstrating a slow increase in the number of plants with symptoms over time. In contrast, MAR20\#2005, EC-3-0, and BRS GA1 exhibited a low percentage of plants with symptoms in the first evaluation, but quickly achieved high incidence scores on assessment three. Since no immune P. edulis genotype has been detected to date, it is expected that disease severity and incidence increase over time, ultimately reaching $100 \%$ incidence. Nonetheless, it is likely that plants with greater resistance degree could have PWD symptom expression delayed. Hence, along with severity assessments, evaluations of PWD incidence over time could be useful in screening for disease resistance in early disease development stages.

Table 4. Passion fruit woodiness disease (PWD) incidence (DIE; \%) in sour passion fruit (Passiflora edulis Sims) mechanically inoculated with Cowpea aphid-borne mosaic virus (CABMV), in Brasilia, DF, Brazil

\begin{tabular}{llllll}
\hline \multirow{2}{*}{ Progeny } & \multicolumn{5}{c}{ Incidence at each evaluation date (DIE) } \\
\cline { 2 - 6 } & E1 & E2 & E3 & E4 & E5 \\
\hline FB200 & $65.0 \mathrm{aA}$ & $70.0 \mathrm{aA}$ & $80.0 \mathrm{aA}$ & $85.0 \mathrm{aA}$ & $85.0 \mathrm{aA}$ \\
Rosa Intenso 1 & $44.2 \mathrm{aB}$ & $55.4 \mathrm{bB}$ & $72.1 \mathrm{aA}$ & $72.1 \mathrm{bA}$ & $72.1 \mathrm{bA}$ \\
MAR20\#39 & $49.6 \mathrm{aB}$ & $77.5 \mathrm{aA}$ & $77.5 \mathrm{aA}$ & $82.5 \mathrm{aA}$ & $82.5 \mathrm{aA}$ \\
UnB2015-2 & $46.7 \mathrm{aB}$ & $46.7 \mathrm{bB}$ & $81.7 \mathrm{aA}$ & $86.7 \mathrm{aA}$ & $86.7 \mathrm{aA}$ \\
Rosa Intenso 2 & $43.8 \mathrm{aB}$ & $47.9 \mathrm{bB}$ & $79.2 \mathrm{aA}$ & $83.3 \mathrm{aA}$ & $83.3 \mathrm{aA}$ \\
MAR20\#41 & $15.0 \mathrm{bB}$ & $25.0 \mathrm{cB}$ & $40.0 \mathrm{bA}$ & $55.0 \mathrm{bA}$ & $60.0 \mathrm{bA}$ \\
MAR20\#2005 & $27.1 \mathrm{bC}$ & $54.2 \mathrm{bB}$ & $95.8 \mathrm{bA}$ & $95.8 \mathrm{aA}$ & $95.8 \mathrm{aA}$ \\
Rubi Gigante 2 & $35.0 \mathrm{bB}$ & $65.8 \mathrm{aA}$ & $86.7 \mathrm{aA}$ & $86.7 \mathrm{aA}$ & $86.7 \mathrm{aA}$ \\
MAR20\#24 & $60.0 \mathrm{aB}$ & $81.7 \mathrm{aA}$ & $86.7 \mathrm{aA}$ & $90.8 \mathrm{aA}$ & $95.8 \mathrm{aA}$ \\
AR2 & $62.1 \mathrm{aA}$ & $76.3 \mathrm{aA}$ & $85.4 \mathrm{aA}$ & $85.4 \mathrm{aA}$ & $85.4 \mathrm{aA}$ \\
EC-3-0 & $23.3 \mathrm{bB}$ & $42.1 \mathrm{bB}$ & $85.4 \mathrm{aA}$ & $95.8 \mathrm{aA}$ & $95.8 \mathrm{aA}$ \\
BRS GA1 & $39.2 \mathrm{bB}$ & $55.8 \mathrm{bB}$ & $95.8 \mathrm{aA}$ & $95.8 \mathrm{aA}$ & $95.8 \mathrm{aA}$ \\
\hline
\end{tabular}

Note. $\mathrm{E}=$ Evaluations; DI $=$ Mean incidence scores of five evaluations. Different lowercase letters within columns and uppercase letters within rows indicate significant differences (Scott-Knott's test, $\mathrm{P} \leq 0.05$ ).

Such evaluations are especially important when PWD severity and incidence are positively and strongly correlated, as observed in this study $(0.83 ; \mathrm{P} \leq 0.01)$. Strong correlations between disease severity and incidence demonstrate that greater disease incidence is related to higher severity scores. Such correlations have also been 
reported for PWD and bacterial spot in several studies (Viana et al., 2014b; Nogueira, 2016; Costa et al., 2018b). Therefore, such analyses are of great importance during plant selection. Moreover, Costa et al. (2018a) reported a contrasting response from progenies regarding bacterial spot and PWD. The authors found that progenies with greater resistance to bacterial spot showed greater susceptibility to PWD. Our study evaluated plant response to distinct isolates used by those authors when inoculated in the same dates from that experiment. However, no correlation was recorded between bacterial spot and PWD when Xap was inoculated before CABMV. Hence, further studies are necessary in order to better understand plants response to different diseases and possible existing correlations between bacterial spot and PWD.

Low heritability value was observed for bacterial spot incidence $(14.0 \%)$; medium magnitude values were identified for PWD severity (45.6\%) and AUDPC of PWD (39.8\%); and high heritability estimate was detected for PWD incidence (59.2\%). Heritability is a measurement of how much of the phenotypic variation is due to genotypic variation (Falconer \& Mackay, 1996). It expresses the correlation between phenotype and genotype allowing one to understand if the differences detected present a genetic background and if selection will provide gains in genetic breeding programs (Silva, Pio Viana, Amaral, Gonçalves, \& Reis, 2012). Traits presenting medium magnitude of heritability estimates do not entail on inefficient selection. Contrariwise, these traits can be improved. However, gains per cycle will be lower as they will be moderately inherited (Assunção, Krause, Dallacort, Santos, \& Neves, 2015).

AUDPC is a useful measurement of disease intensity over time. It entails repeated disease assessments and allows for characterization of plant-pathogen-environment interactions (Simko \& Piepho, 2012). In this study, AUDPC was calculated for disease severity. However, no differences were found among progenies for bacterial spot and PWD.

GCV/ECV was only 0.2 for bacterial spot incidence; $0.5,0.6$, and 0.4 for PWD severity, incidence, and AUDPC, respectively. Overall, these data indicate that there is low genetic variability within progenies and/or environmental conditions were not favorable for selection since the environmental variance was greater than the genotypic variance. High ECV values do not necessarily mean experimental imprecision, since they may indicate that the trait under study is of polygenic inheritance and, as a result, is highly affected by the environment. In situations like this, the use of more elaborate breeding methods, such as the ones based on family performance, are more suitable for obtaining satisfactory gains during selection (Silva et al., 2012).

\section{Conclusion}

The bacterial spot and PWD severity and incidence degrees observed in this study reveal the existence of variability within progenies. MAR20\#2005 and BRS GA1 stood out as the progenies with the lowest bacterial spot severity scores. MAR20\#41, MAR20\#2005, and Rosa Intenso 1 were selected as the progenies with the lowest PWD severity scores. MAR20\#41 also exhibited the highest number of plants presenting resistance to the PWD at the end of five evaluations. For that reason, MAR20\#41 was selected as the most promising progeny to be used in the breeding programs with focus on PWD resistance. MAR20\#2005 was selected as the most promising progeny to be used in breeding programs with emphasis on disease resistance due to its superior performance to both bacterial spot and PWD. The selected progenies will be cloned and, again, assessed for bacterial spot and PWD resistance at different seasons, providing means of following up with the breeding program on disease resistance.

\section{Acknowledgements}

This study was financed, in part, by the Coordenação de Aperfeiçoamento de Pessoal de Nível Superior-Brasil (CAPES)-Finance Code 001. The authors also thank Dr. Michelle Souza Vilela for her guidance with the statistical analyses.

\section{References}

Alvares, C. A., Stape, J. L., Sentelhas, P. C., Gonçalves, J. L. M., \& Sparovek, G. (2013). Köppen's climate classification map for Brazil. Meteorologische Zeitschrift, 22(6), 711-728. https://doi.org/10.1127/09412948/2013/0507

Assunção, M. P., Krause, W., Dallacort, R., Santos, P. R. J., \& Neves, L. G. (2015). Seleção individual de plantas de maracujazeiro azedo quanto à qualidade de frutos via REML/BLUP. Revista Caatinga, 28, 57-63.

Bellon, G. (2014). Filogenia, variabilidade genética e caracterização de passifloras silvestres, comerciais e híbridos interespecíficos como fontes de resistência à doenças (Doctoral dissertation, University of Brasilia, Brasilia, Brazil). Retrieved from http://repositorio.unb.br/handle/10482/15872 
Campbell, C. L., \& Madden, L. V. (1990). Introduction to plant disease epidemiology. New York, NY: John Wiley.

Carvalho, F. I. F., Lorencetti, C., \& Benin, G. (2004). Estimativas e implicações da correlação no melhoramento vegetal. Pelotas, RS: Ed. Universitária da UFPel.

Carvalho, S. L. C., Stenzel, N. M. C., \& Auler, P. A. M. (2015). Maracujá-amarelo: Recomendações técnicas para cultivo no Paraná. Londrina, PR: IAPAR.

Costa, A. P., Nogueira, I., Peixoto, J. R., Blum, L. E. B., Vilela, M. S., \& Vendrame, W. (2018b). Reaction of yellow passion fruit to passion fruit woodiness disease and to bacterial spot. Bioscience Journal, 34,189-196. https://doi.org/10.14393/BJ-v34n6a2018-39686

Costa, A. P., Nogueira, I., Peixoto, J. R., Vilela, M. S., Blum, L. E. B., \& Vendrame, W. (2018a). Yellow passion fruit reaction to Xanthomonas axonopodis pv. passiflorae and to Cowpea aphid-borne mosaic virus. Crop Breeding and Applied Biotechnology, 18(4), 349-356. https://doi.org/10.1590/1984-70332018v18n4a53

Falconer, D. S., \& Mackay, T. F. C. (1996). Introduction to quantitative genetics (4th ed.). Harlow: Longmans Green.

Fuhrmann, E., Junqueira, N. T. V., Blum, L. E. B., Braga, M. W., Bellon, G., \& Junqueira, K. P. (2014). Reação de híbridos interespecíficos de Passiflora spp. à Xanthomonas axonopodis pv. passiflorae. Ciência Rural, 44(8), 1404-1410. https://doi.org/10.1590/0103-8478cr20121092

Junqueira, N. T. V., Anjos, J. R. N., Silva, A. P. O., Chaves, R. C., \& Gomes, A. C. (2003). Reação as doenças e produtividade de onze cultivares de maracujá-azedo cultivados sem agrotóxicos. Pesquisa Agropecuária Brasileira, 38(8), 1005-1010. https://doi.org/10.1590/S0100-204X2003000800014

Junqueira, N. T. V., Sussel, A. A. B., Junqueira, K. P., Zacaroni, A. B., \& Braga, M. F. (2016). Doenças. In F. G. Faleiro, \& N. T. V. Junqueira (Eds.), Maracujá: O produtor pergunta, a Embrapa responde (pp. 169-180). Brasilia, Brazil: Embrapa Cerrados.

Melo, C. L. P., Ragagnin, V. A., Arruda, K. M. A., Barros, E. G., Carneiro, P. C. S., Paula Júnior, T. J., ... Carneiro, J. E. S. (2008). Caracterização fenotípica e molecular de genitores de feijão tipo carioca quanto à resistência a patógenos. Pesquisa Agropecuária Brasileira, 43, 495-504. https://doi.org/10.1590/S0100-204 X2008000400008

Nascimento, A. V. S., Santana, E. N., Braz, A. S. K., Alfenas, P. F., Pio-Ribeiro, G., Andrade, G. P., ... Zerbini, F. M. (2006). Cowpea aphid-borne mosaic virus (CABMV) is wide spread in passion fruit in Brazil and causes passion fruit woodiness disease. Archives of Virology, 151(9), 1797-1809. https://doi.org/10.1007/ s00705-006-0755-6

Neder, D. G., Pinto, C. A. B. P., Melo, D. S., Lepre, A. L., \& Peixouto, L. S. (2010). Seleção de clones de batata com resistência múltipla à pinta preta e aos vírus X e Y. Ciência Rural, 40, 1702-1708. https://doi.org/ 10.1590/S0103-84782010000800005

Nogueira, I. (2016). Caracterização agronômica e físico-química de progênies de maracujazeiro azedo (Passiflora edulis Sims) no Distrito Federal (Master's thesis, University of Brasilia, DF, Brazil). https://doi.org/10.26512/2016.02.D.21097

Peruch, L. A. M., Colariccio, A., \& Schroeder, A. L. (2011). Sintomas e controle das principais doenças do maracujazeiro (Passiflora edulis f. flavicarpa) em Santa Catarina. Agropecuária Catarinense, 24(2), 42-45.

Santos, E. A., Pio Viana, A., Freitas, J. C. O., Silva, F. H. L., Rodrigues, R., \& Eiras, M. (2015). Resistance to Cowpea aphid-borne mosaic virus in species and hybrids of Passiflora: advances for the control of the passion fruit woodiness disease in Brazil. European Journal of Plant Pathology, 143(1), 85-98. https://doi.org/10.1007/s10658-015-0667-y

Silva, M. G. M., Pio Viana, A., Amaral Jr., A. T., Gonçalves, L. S. A., \& Reis, R. V. (2012). Biometria aplicada ao melhoramento intrapopulacional do maracujazeiro amarelo. Revista Ciência Agronômica, 43(3), 493-499. https://doi.org/10.1590/S1806-66902012000300011

Simko, I., \& Piepho, H. P. (2012). The area under the disease progress stairs: Calculation, advantage, and application. Analytical and Theorical Plant Pathology, 102(4), 381-389. https://doi.org/10.1094/ PHYTO-07-11-0216

Viana, C. A. S., Pires, M. C., Peixoto, J. R., Junqueira, N. T. V., \& Blum, L. E. B. (2014a). Genótipos de maracujazeiro-azedo com resistência à bacteriose. Bioscience Journal, 30, 591-598. 
Viana, C. A. S., Pires, M. C., Peixoto, J. R., Junqueira, N. T. V., \& Blum, L. E. B. (2014b). Resistência parcial de genótipos de maracujá-azedo à virose do endurecimento do fruto (Cowpea aphid-borne mosaic virus-CABMV). Bioscience Journal, 30, 338-345.

Wisser, R. J., Kolkman, J. M., Patzoldt, M. E., Holland, J. B., Yu, J., Krakowsky, M., ... Balint-Kurti, P. (2011). Multivariate analysis of maize disease resistances suggests a pleiotropic genetic basis and implicates a GST gene. Proceedings of the National Academy of Sciences, 108, 7339-7344. https://doi.org/10.1073/pnas. 1011739108

\section{Copyrights}

Copyright for this article is retained by the author(s), with first publication rights granted to the journal.

This is an open-access article distributed under the terms and conditions of the Creative Commons Attribution license (http://creativecommons.org/licenses/by/4.0/). 